\title{
Geopolitics of disregard: Living a colonial life in Okinawa
}

Hidefumi Nishiyama

Published in Political Geography, 74 (2019), https://doi.org/10.1016/j.polgeo.2019.102042.

\section{$\underline{\text { ABSTRACT }}$}

This article aims to make a contribution to the field of critical geopolitics by exploring two rather underexamined facets of contemporary imperial geopolitics. First, the article suggests that the concept of disregard developed by Stoler can shed new light on everyday life at the margins of imperial geopolitics. Stoler argues that living a colonial life entails acts of disregarding certain forms of violence and injustice without fully accepting the colonial system as a whole. In conjunction with Memmi's earlier portrait of the colonised, Stoler's writing helps to understand the complexities and ambivalence that the colonised go through living in and off an empire. Second, the article demonstrates how practices of disregard play out in the (post)colonial and militarised context of Okinawa. Despite its significance in US military mapping, Okinawa remains an understudied site in the field of critical geopolitics. Situating Okinawa in the broader context of imperial geopolitics and its double colonial present, the article explores how islanders come to live their colonial life and make a living whilst disregarding certain colonial conditions.

\section{$\underline{\text { KEYWORDS }}$}

Colonialism, Disregard, Critical Geopolitics, Islands, Military base, Okinawa

\section{Geopolitics of disregard: Living a colonial life in Okinawa}

\section{INTRODUCTION}


In The Colonial Present Gregory (2004) has brought up an important insight about colonialism in contemporary geopolitics. Tracing the genealogy of British and American involvement in the Middle East, Gregory (2004) problematises the so-called "war on terror" in the early twenty-first century as the continuation of, though not exactly the same as, colonial geopolitics of the past. Harvey (2005), for his part, discusses American "new imperialism" that manifested itself in the invasion of Iraq. Existing studies in geography, and in the social and political sciences more broadly, have shown that direct forms of US imperial and colonial domination are very much alive today. The analysis of wars, conflicts, and interventions in places like Afghanistan and Iraq is decidedly of importance for understanding geopolitics and the continuation of colonialism. Yet, there are also other equally crucial sites of colonial geopolitics that are less direct and less explicit than these theatres of war. As Davis (2011: 216) suggests, studies of contemporary imperial and colonial geopolitics need "to be expanded beyond just the 'new' American colonialisms of Iraq and Afghanistan to include some rarely analysed, old, continual, banal, colonialisms that have maintained the framework of American power". After the Second World War, the framework of US military strategy began to heavily rely on base networks of islands such as Puerto Rico, Guam, Hawaii, and Okinawa. Since the 1970s, Diego Garcia has also become one of the most important American bases (Sidaway, 2010; Vine, 2009). These islands were highly militarised during the course of the twentieth century and have become underpinning components of the operation of US geopolitics across the world (Davis, 2011; Herman, 2008; Lutz, 2009). As Vine's (2015: 4-5) study shows, the scale of US overseas bases itself is striking: there are nearly 700 US base sites outside the fifty states and Washington, D.C., which are responsible for over half a million Americans abroad, including troops, family members, and civilian workers. And yet, unlike the theatres of war, the subject is rarely discussed among Americans or in the American media (Vine, 2015: 2-3). These islands are "hidden" (Immerwahr, 2019) parts of American imperial geopolitics. 
Island military bases are of the utmost importance for studies of geopolitics also because they are in themselves the products of earlier colonialism and territorial acquisition. While only Guam is formally recognised as a colony by the United Nations, Puerto Rico, Hawaii and Okinawa all have colonial histories (Davis, 2011: 216). In addition, due to the high concentration of bases and the lack of full democratic rights in places like Guam and Puerto Rico, US bases also help "perpetuate a twenty-first-century form of colonialism" (Vine, 2015: 10). In Okinawa, an archipelago that was colonised by Japan in the late nineteenth century, the colonial present is manifested in violence and injustice towards local residents in their everyday life. There have been a series of crimes committed by US troops and base workers against local residents, including the rape and murder of women and children. Despite the continuation of violence, the US military presence in Okinawa is legitimised by the US-Japan security alliance. The G7 meeting between Prime Minister Abe and President Obama in May 2016 is indicative of this. Following the recent rape and murder of a 20year-old Okinawan woman by a former US Marine, now base worker, Abe expressed apparent anger in the meeting with Obama. As a response, Obama "extended [his] sincerest condolences and deepest regrets" (The White House President Barack Obama, 2016). Neither leader, however, proposed any change to the presence of US bases in Okinawa. Instead, the bilateral meeting concluded with a reaffirmation of the security alliance. It is Okinawa's "double colonisation" (Akibayashi and Takazato, 2009), which manifests itself in the US military's violence and Japan's complicity.

This article explores imperial geopolitics and the colonial present through the case of Okinawa. It particularly focuses on the ways in which people live their everyday life in the colonial base islands. It aims to make a contribution to the field of critical geopolitics by exploring two rather underexamined facets of contemporary imperial geopolitics. The first is conceptual. The article introduces the concept of disregard developed by Ann Laura Stoler (2009: 248) in order to capture 
what she calls "complex psychic space". Living a colonial life, she suggests, entails acts of disregarding certain colonial realities but without ever fully accepting or refusing them. The analysis of disregard is helpful for greater understanding of individual experiences of life in a colonial space. In particular, it helps to understand what it means, and takes, to live under conditions of empire. The second facet is geographical. In light of a lack of consensus on what the term "critical geopolitics" designates and on what needs to be studied within the said field, Dalby (2010: 281) suggests that the disciplinary focus of critical geopolitics should be militarism and war. Accordingly, critical geopolitics is about "explicit rejection of imperialism and domination" (Dalby, 2008: 417). Despite the persistence of colonial violence that is conditioned by US (and Japanese) geopolitical mapping, Okinawa is understudied in this respect. Okinawa is also somewhat neglected in postcolonial geographies despite the richness in this field of research in the past decades (cf. Blunt \& McEwan, 2002; Sidaway, 2000). The marginalisation of Okinawa in postcolonial geographies may be due to the fact that it does not easily fall into the European history of (post-)colonialism and its periodisation (cf. Sidaway, 2000: 596), though studies of marginalised islands are today clearly on the rise in political geography more broadly (Mountz, 2013, 2015).

Drawing on the case of Okinawa, the article argues that the colonised, largely due to economic prospects that US military bases offer, come to live, and to make a living, by disregarding certain colonial conditions they inhabit whilst still embracing a demilitarised future. The structure of the paper is as follows. The first section revisits the existing literature on critical geopolitics, with particular emphasis on banal, feminist, and subaltern geopolitics, and introduces Stoler's concept of disregard. The purpose here is to clarify the location of the concept of disregard within existing critical writing on geopolitics and how the concept can make a contribution to it. The section concludes with the suggestion that Stoler's conceptualisation, which draws on the analysis of the coloniser, can constructively apply to the analysis of the colonised that Albert Memmi (2003) 
previously employed. The second section offers a concise account of Okinawa's double colonial present. The third section explores the ways in which local residents in Okinawa come to disregard particular colonial conditions they live in. It particularly focuses on the 2018 mayoral election in Nago, a city in the northern part of the island, in which the conservative-government-backed candidate won against the incumbent anti-base mayor. Drawing from interviews conducted by local and national news media, the section illustrates the ambivalence felt among Okinawans towards US bases and instances of disregard among them. The article concludes with agendas for future studies of disregard not only in Okinawa but also in other islands such as Guam, which is currently a major destination for the relocation of US soldiers in Okinawa.

\section{CRITICAL GEOPOLITICS AND "POLITICS OF DISREGARD”}

In the past three decades, critical geopolitics has grown in theoretical sophistication (Dodds, 2001;

Dodds, Kuus \& Sharp, 2013; Power \& Campbell, 2010). Accordingly, there has been a proliferation of adjectives attached to the field (Sidaway, Mamadouh \& Power, 2013: 183). These adjectives include "banal", "feminist", "popular", "radical", "subaltern", and the recently suggested "liminal" (Dittmer \& Dodds, 2008; Dodds, 2000; Dowler \& Sharp, 2001; Hyndman, 2007; Kuus, 2007; McConnell, 2017; Mercille, 2008; Sharp, 2000, 2011a, 2011b, 2013; Sidaway, 2008, 2012). The geopolitics of disregard is not meant to replace existing theoretical frameworks in critical geopolitics. Rather, drawing from existing theories, and developing a dialogue with them, the article introduces the concept of disregard in order to address some of the complexities that are embedded in contemporary imperial geopolitics. To be clear, the geopolitics of disregard does not constitute an independent theoretical framework. Disregard is an analytical concept that can be utilised together with existing critical approaches to throw new light on geopolitics. 
There are three distinct, though closely related, primary existing approaches that are relevant to the present study: banal, feminist, and subaltern geopolitics. Banal geopolitics underscores the ubiquity and omnipresence of geopolitics. There has recently been a debate as to whether this focus on the "everydayness" of geopolitics actually makes an original contribution, and thus some clarification is required. Citing Sidaway’s (for example, 2008) commentaries, Ciută and Klinke (2010: 330) dismiss banal geopolitics as virtually equivalent to popular geopolitics. Sidaway (2008) articulates banal geopolitics in temporal and spatial terms. Geopolitics is "banalised" in time because contemporary war and intervention become "normalized", "unexceptional" and "without end", as in the case of the global "war on terror" (Sidaway, 2008). Geopolitics is also "banalised" in space. Sidaway (2008: 2) discusses the role of the media and how they "banalise" war and make it a “daily” routine. Ciută and Klinke (2010: 330) argue that the role of "daily media coverage" in banal geopolitics makes its original contribution indistinct since this is already the focal point of popular geopolitics. However, despite its similarity to popular geopolitics, banal geopolitics should not be reduced to the analysis of discourse and representation in the media and other domains of popular culture. "Daily media coverage" is only one aspect of the banality of geopolitics. In order to illustrate this point, it is worth revisiting earlier research on banality and its influence on the field of critical geopolitics.

As Dodds (2001: 473) notes, the early years of critical geopolitics predominantly focused on discourse and representation at the macro-level (for example, national symbols). Consequently, it tended to overlook how people's everyday lives become part of the process of geopolitical formations. The discourse analysis of media representation was a method that moved beyond the macro-level. Yet, there was a lack of attention to what Thrift (2000) calls "the little things", mundane things and practices, and human bodies themselves. "The little things" are not fully captured by textual analysis and yet equally shape and are shaped by geopolitics. Billig's (1995) 
work on banal nationalism supplements critical geopolitics by showing how everyday practices are entwined with particular representations of world politics. Banal nationalism shows how geopolitics is "activated" at the individual level (Dodds, 2000: 121). Paasi (1996), for his part, explores the geopolitical shaping of individuals. For example, national independence is not only narrated and represented but also embedded in material landscapes and performed through rituals (Paasi, 2016). Thus, banal geopolitics, when understood in these broader terms, is a theoretical framework that investigates the ubiquity and omnipresence of geopolitics. It examines how geopolitics is practiced and performed by individuals, and in turn, how a geopolitical context shapes individuals, beyond media representations.

Feminist geopolitics also takes individuals in everyday life as a key site of analysis, but with a particular focus on the issues of marginality (Dowler \& Sharp, 2001; Hyndman, 2007; Sharp, 2000). Sharp (2000) notes that despite its important contributions, Ó Tuathail's Critical Geopolitics (1996) paid little attention to the role of gender and other social categories. This is not to say that he did not recognise the fact that geopolitics has been gendered. In fact, Ó Tuathail (1996: 58-86) discussed how earlier geopolitical writing, the work of Mackinder in particular, is both gendered and racialised. Yet, there is still a tendency in his account to focus on state actors. Feminist geopolitics recognises individual experiences, particularly those of the marginalised such as women. Their experiences are often written off in the analysis of statecraft despite the fact that they contribute to statecraft. As Dowler and Sharp (2001: 169) state, feminist geopolitics recognises "the inherent and unavoidable embodiment of geographical processes and geopolitical relationships at different scales". To introduce the feminist slogan "the personal is political" to the field of critical geopolitics means also to examine "the complex relations between the international and everyday" in order to "demonstrate the importance of ensuring that small, mundane daily practices of everyday life are understood in relation to the reconstructions of the nation and the international" (Dowler \& 
Sharp, 2001: 174). For Hyndman (2007), feminist geopolitics shifts the focus of analysis from the macrosecurity of states to the microsecurity of (marginalised) people. Feminist geopolitics "offers more epistemologically embodied accounts of war that more effectively convey the loss and suffering of people affected by it" (Hyndman, 2007: 36). As will be explored in the subsequent sections, it is also important to note that it was feminist scholars and activists who helped to bring to the fore the marginality of Okinawans who continue to confront gendered violence and injustice.

The more recent introduction of subaltern geopolitics further advances the analytical focus on the marginalised (Sharp, 2011a, 2011b, 2013; Sidaway, 2012). While feminist geopoliticians already drew from postcolonial theories, by adopting the term "subaltern" this body of scholarship takes more explicitly a postcolonial mode of enquiry to geopolitics in a similar manner to what Slater (2004) earlier called "postcolonial geopolitics". For Sharp (2011b: 271), the term subaltern geopolitics is used to highlight a postcolonial emphasis that brings in "the voices of those usually rendered marginal and silent in other accounts". Subaltern geopolitics is about taking the ambiguity of the marginalised into serious consideration (Woon, 2011). The recognition of the ambiguous position of the marginalised is important in order to go beyond binary categories ("Self/Other", "Western/Non-Western"), which may reinforce the centrality of the dominant geopolitics. This is what Bhabha (2004) conceptualises as "mimicry": "Mimicry does not suggest the Other wishing to become the same, or that it is radically different, but instead destabilises these binalised categories" (Sharp, 2013: 22). By bringing in the voice of the marginalised, without reducing it to such binalised categories, subaltern geopolitics aims to "offer alternative ways of imagining and doing geopolitics" (Sharp, 2011b: 271).

With respect to these theoretical developments, critical geopolitics then can be summarised as follows. First, it pays close attention to mundane and banal practices for a greater understanding of 
geopolitics. Geopolitics operates in everyday life where hegemonic power relations are reproduced. Second, it equally pays attention to those who are marginalised from dominant geopolitics. Third, an analysis of the marginalised should entail the bringing of their voice rather than reducing the focus to the juxtaposition of marginalised and dominant (often Western) geopolitics. As I will discuss later in the article, Okinawa is of great importance for critical geopolitics in these senses: it is important not simply because it is an crucial geostrategic location for US military but also because violence and injustice that US bases cause against local residents are typically banalised and need to be challenged through the lens of the (often gendered) marginalised.

Ann Laura Stoler's (2009) analysis of colonialism helps to advance the existing critical writings of geopolitics by interrogating and complicating ambiguity in colonial life. Stoler (2009) suggests that colonialism is not something one can simply refuse or accept. Her starting point is a rejection of the idea that "we who study the colonial know both what imperial rule looks like and the dispositions of those it empowers" (2009: 238). Stoler (2009: 247-8) critically revises the role of knowledge and ignorance in the (re)production of imperialism that postcolonial scholars had previously underscored. For example, Said (2001) denounced Huntington's idea of "the clash of civilisations" as "the clash of ignorance" in his commentary on post-9/11 Islamophobia: "The challenge for Western policy-makers, says Huntington, is to make sure that the West gets stronger and fends off all the others, Islam in particular. . . Huntington is an ideologist, someone who wants to make 'civilizations' and 'identities' into what they are not: shut-down, sealed-off entities that have been purged of the myriad currents and countercurrents that animate human history". For Said (2001), "The clash of civilisations" is a form of ignorance that does nothing but reinforce "defensive selfpride". Du Bois (1920: 39), for his part, asked in the early twentieth century: Why is European culture "better than any culture that arose in Africa or Asia?" European superiority, Du Bois (1920: 
40) argued, is created by "the deliberately educated ignorance of white schools by which they remember Napoleon and forget Sonni Ali”.

Stoler reflects particularly on Albert Memmi's work on colonialism. Memmi cautioned that colonialism cannot be simply reduced to the dichotomous relationship between the two categories of the coloniser and the colonised. Memmi (2003) discusses the psychological effects of colonialism on individuals and identifies mechanisms of colonialism that operate within each category. For Memmi, there are two kinds of colonisers. On the one hand, witnessing endemic poverty, violence, and injustice in a colony, a coloniser may refuse colonisation: "It sometimes happens that a new arrival - astonished by the large number of beggars, the children wandering about half-naked, trachoma, etc., ill at ease before such obvious organization of injustice, revolted by the cynicism of his own fellow citizens [...], immediately thinks of going home" (Memmi, 2003: 63). Other refusers may not go home but stay in a colony and "protest, or sign a petition, or join a group which is not automatically hostile toward the colonized" (Memmi, 2003: 64). Yet, this may do little but change the difficulties and discomfort confronting the coloniser because "it is not easy to escape mentally from a concrete situation, to refuse its ideology while continuing to live with its actual relationships" (Memmi, 2003: 64).

On the other hand, there is the coloniser who accepts. Memmi (2003: 89) observed that for a coloniser it is "more convenient to accept colonization". This is because a coloniser who refuses colonisation yet stays continues to live in contradiction, and cannot resolve his anguish unless he leaves the colonial life and its privileges behind (Memmi, 2003: 89). A coloniser may accept colonisation not necessarily because he enjoys oppressing native people but because of economic opportunities (Memmi, 2003: 90) and/or the psychological privilege he acquires. "Although he is everything in the colony," wrote Memmi (2003: 105), "the colonialist knows that in his own 
country he would be nothing”. In Memmi's account, Stoler (2009: 247) notes, those who accept colonisation, while recognising their privileged position and violence against the colonised, "selfcensure" and live "a feigned ignorance": they are "those who turn their backs on what they know". As with the other aforementioned postcolonial accounts, Stoler argues that ignorance plays an important role in Memmi's understanding of the mechanisms of colonialism.

It is this assumed role of ignorance in colonialism that Stoler problematises, and in doing so, she introduces the concept of disregard. The postcolonial critique of ignorance in these accounts, she suggests, needs to be questioned, if not rejected. According to Stoler (2009: 248), these accounts are predicated on assumptions such as: that empires foster the cultivation of ignorance by limiting and obscuring knowledge; that the acquirement of knowledge weakens and destabilises empires and imperial practices; and that knowledge leads people to take actions against imperialism. More crucially, these accounts are founded upon the idea that the clear-cut distinctions - between knowledge and ignorance, or between acceptance and refusal - can effectively portray "both the cognitive conditions and political choices of empire's European and American agents and actors" (2009: 248). This is inadequate, she argues, because it fails to recognise the more complex processes that individuals in a colony go through.

As with Memmi, Stoler analyses colonialism through the perspective of colonial life; she looks at the ways in which individuals live their everyday life in a colony and how their dispositions are shaped, and yet not completely overridden, by the macropolitics of imperialism. Stoler (2009: 249) departs from Memmi by examining the psychic space that spans the colonial life, which is "messier and [more] unsettling" than that which the distinctions between knowledge and ignorance, and between acceptance and refusal, can capture. Stoler (2009) conducts an archival study on the Dutch East Indies and closely examines the official and private correspondence of Frans Carl Valck, then 
Assistant Resident of Deli, North Sumatra, in the late nineteenth century. Valck witnessed the colonial officials" corruption and the "atrocities" of "so-called civilized Europeans" and the corresponding impoverishment of natives (Stoler, 2009: 204-5). He was vocal and reported such corruption to the General Secretary to the Governor-General, critically claiming that the real situation needs to be known widely (Stoler, 2009: 201). Valck's condemnation was a risky choice: his reports of "European barbarism on the Deli estates" cost him his job: he was dismissed within a few years of his arrival in Deli at the age of 43 (Stoler, 2009: 238). Yet, though not high-profile, Valck was a member of the privileged European elite, who was born to a father who had held prestigious posts in colonial Java and married to a daughter of a family whose fortune was made in the central Javanese sugar industry (Stoler, 2009: 228, 249-250). As such, he, though at times vocal in denouncing the wrongs of colonialism, was also deeply complicit in the colonial enterprise. Stoler turns her analysis to his private letters, which reveal his "imperial dispositions". Despite his awareness of corruption in the Dutch East Indies, Valck sometimes conformed colonial stereotypes and narratives, characterising natives as "untrustworthy" and underscoring the need for the use of "fear" to control them (Stoler, 2009: 256, 276). On top of that, he chose not to recognise or pay attention to certain realities of colonial violence and injustice in his everyday life.

Stoler proposes what she calls a "politics of disregard" to capture this complex psychic space in the minds of colonisers. The politics of disregard, as she (2009: 51) defines it, is "the psychological and political machinations it takes to look away for those who live off and in empire". Those who make a living within a colonial system, and thus whose life (and privilege) is more or less dependent on it, sometimes deter themselves from engaging in acts against the very system of colonialism. Such acts of "looking away", rather than simply direct engagements with colonial violence, characterises imperial dispositions. Stoler (2009: 256, italic original) suggests: "Most importantly, imperial dispositions are marked by a negative space: that from which those with privilege and standing 
could excuse themselves. I call this ability to excuse oneself from wrought engagement, this refusal to witness and the almost legal legitimacy it confers, the well-tended conditions of disregard". She underscores that imperial dispositions and acts of disregard do not necessarily mean full acceptance of colonialism. Colonial officers such as Valck were not completely ignorant; at times, they engaged in acts of refusal. Yet, they did not unconditionally refuse the colonial enterprise, which constituted the basis of their existence, and thus would have eventually destabilised their own life. Disregard, in this sense, resembles with what Simmel (1950: 310) called Lebensluge, a "vital lie", or a "lie for life", with which one deceives oneself so that one's life can be maintained (Stoler, 2009: 259-60). Such a lie, for Stoler, is coded by imperialism and is constitutive of imperial dispositions. Stoler's conceptualisation of disregard is a postcolonial intervention to Simmel's more general socio-psychological theorisation of "lie for life".

Stoler's concept of disregard appears to agree with Memmi's (2003: 62) portrait of the coloniser who practices "inevitable self-censure". In fact, Memmi already noted the ambiguous status of the coloniser. One difference between Stoler and Memmi appears to be subtle, which lies in their analytical focus. While Memmi focused on the eventual decision of the coloniser, Stoler focuses on the continuous process of the coloniser's lived experience. For Stoler, acceptance is hardly a completed act. Colonial officers such as Valck may be seen as "the coloniser who accepts" (Memmi, 2003) as he continued to live a colonial (and coloniser's) life. Yet, he never completely accepted the very system that sustained his privilege and comfort; in fact, he had critiques and doubts towards it. Not simply refusal or acceptance, but the coloniser's life spans refusal and acceptance, ignorance and knowledge, and colonial politics and the everyday. Attentive to the complexities that living a colonial life entails, the concept of disregard can contribute to studies of the banality of power and banal geopolitics. Disregard is a form of banality that pays attention to inattention and the "averted gaze" (Stoler, 2009: 255). Individuals disregard certain things and 
aspects of life whilst their acts of disregard are nourished by, as well as reproduce, the broader political structure of a particular time and space. What a banal geopolitics of disregard attempts to deconstruct is not how everyday language banalises world politics (cf. Dodds, 2000: 121-2). Rather, it attempts to deconstruct the contradictions and ambiguity in individual lives that are constituted by a given political situation but are "never wholly subsumed by it" (Stoler, 2009: 51).

The concept of disregard can also supplement subaltern and postcolonial writing of geopolitics when it is brought to bear on one of the two main aspects of Memmi's study that Stoler neglects: the portrait of the colonised. The colonised, Memmi reminds us, attempt to transform their oppressed position in one of two ways: liberation or assimilation. Liberation is the denial of the coloniser; it means "self-discovery" (Memmi, 2003: 172). Assimilation, by contrast, is "selfdenial". In this attempt, the colonised accede to colonisation, the process in which they simultaneously disapprove themselves (Memmi, 2003: 60). As with his portrait of the coloniser, however, Memmi focuses on the resulting outcomes of struggle of the colonised. Bringing Stoler's analytical focus on process, rather than decision or outcome, to the analysis of the colonised is not to reduce the portrait of the colonised to either liberation or assimilation. It means to analyse "the generative power of a 'vital lie"' (Stoler, 2009: 278), or indeed the power of disregard, and how it (re)produces the system of colonialism. An analysis of acts of disregard among the colonised can then contribute to studies of the marginalised that have been underscored by subaltern (and feminist) geopolitics. It brings forward the voice of the marginalised not simply as a counternarrative of dominant geopolitics. It is not simply about bringing in silenced voices. Rather, it takes the ambiguous position of the marginalised into serious consideration by focusing on their voice as a manifestation of the entanglement and estrangement between colonial geopolitics and the everyday life of the colonised. How, then, may practices of disregard play out in contemporary 
imperial geopolitics? The remaining of the paper explores a geopolitics of disregard on islands experiencing double colonisation.

\section{THE DOUBLE COLONIAL PRESENT IN OKINAWA}

In 1879 the archipelago that was formerly known as the Ryukyu Kingdom, now as Okinawa prefecture, was formally annexed to Imperial Japan. Like many other colonies, colonialism in Okinawa has a long and complex history and cannot be fully explored in the present study (for a longer historical analysis, see Oguma, 2014). For one thing, the common depiction of Okinawa as an unequivocal victim of colonialism neglects the complex histories of conquest and domination within the archipelago that took place prior to Japan's colonisation as well as linguistic and cultural variations between the island groups (Hook \& Siddle, 2002: 12). The discussion of Okinawa's colonial history here is inevitably brief, with the main purpose being to situate Okinawa's colonial present vis-à-vis imperial geopolitics and the context in which acts of disregard take place. Feminist scholars and activists Akibayashi and Takazato (2009) characterise Okinawa's colonial present as a “double colonisation" by Japan and the United States, which can trace its foundation back to the late nineteenth century. Prior to the seventeenth century, the islands were recognised as the Ryukyu Kingdom, an independent realm yet under the influence of the Ming Dynasty. The invasion by Satsuma Domain in the seventeenth century resulted in the partial subordination of the kingdom to Satsuma under the feudal Tokugawa system. The subordination was partial as the islands still maintained the vassal relationship with the Ming, and later Qing, dynasties and did not lead to the abolishment of the kingdom. It was during the beginning of Japanese imperialism that the kingdom was formally colonised. The Meiji government started actions to overthrow, or "dispose of", the Ryukyu Kingdom in the 1870s - known as Ryukyu shobun ("Ryukyu Disposal”) - and eventually annexed the islands as Okinawa prefecture at the end of the decade. 
Japan's colonial violence - economic, epistemic, physical, or otherwise - against Okinawans was blunt since the early years of the annexation. There were a number of colonial inequalities by the early twentieth century. They include: the imposition of Japanese language and education; the predominance of Japanese men's ownership of businesses in the islands; significant income inequality; and disproportionate taxation (Siddle, 1998). Highly racialised representation of Okinawans was also prevalent. As with the Chinese and Koreans during the Japanese imperial period, Okinawans were regarded as an "inferior" people who needed to be "led", "improved", "civilised", or "Japanised" (Siddle, 1998: 122-8). The "Hall of Mankind" (Jinrui kan) incident at the 1903 Osaka Industrial Exposition was an exemplar of the Japanese colonial imaginary. Prominent anthropologist Tsuboi Shōgorō proposed the "Hall of Mankind" to display the "natural" lives of non-Japanese groups. His plans to exhibit Chinese, Koreans, and Okinawans were eventually dropped after their strong opposition to being described as "primitives" (Weiner, 1997: 114). The colonial, or "disposable", status of Okinawa continued to manifest itself in the horrific violence Okinawans experienced during the Second World War. The Battle of Okinawa was not only one of the bloodiest military engagements of the war, but also a civilian tragedy in which a quarter of Okinawans died during the combat with the United States. Some of them were killed by Japanese soldiers who "prioritized military strategies over protecting civilian Okinawan lives" (Akibayashi \& Takazato, 2009: 249). There were also incidents of "mass suicide" whereby “Okinawan civilians, mainly children, women, and the elderly, killed each other to avoid surrendering to the enemy, which imperial education had strictly taught was a deep shame and a betrayal of the emperor" (Akibayashi \& Takazato, 2009: 249).

The second part of the duality of Okinawa's colonial present was developed after the war during the ostensible "decolonisation" process of the islands. In 1951, the Japanese government signed the San Francisco Peace Treaty and recovered sovereignty the following year. The treaty included the 
provision that the United States will retain the right to exercise powers over Okinawa and Okinawans. At first glance, the United States appeared to recognise the islands' independence prior to Japanese annexation. Since the early military occupation, they gave preference to the pre-colonial name "Ryukyu" rather than Okinawa. In 1952, they established the Government of the Ryukyu Islands, seemingly granting local Okinawans self-government. In practice, however, the islands remained controlled by the US military who retained authority over the government. Thus, the defeat of the empire in 1945 did not lead to the decolonisation of Okinawa. Instead, the islands were recolonised (Akibayashi and Takazato, 2009: 249).

The US military occupation of Okinawa formally ended in 1972 with the "returning" of the islands to Japan. Yet, the de facto military occupation of the islands continues to this day. During the war, many parts of the islands were appropriated by the US military and the size of military installations in the islands continued to grow after the war. By the 1950 s, more than $40 \%$ of Okinawa's farmland had been appropriated by the United States, displacing almost half of the islanders (Vine, 2015: 75). The signing of the 1971 Okinawa Reversion Agreement between Japan and the United States, it was hoped among Okinawans, would decrease the scale of US bases, but made no substantial change. The amount of land occupied by US military today attests to the continuity of military colonialism. Okinawa prefecture comprises only $0.6 \%$ of the national land. Within this less-than-one-percent of land, as of March 2017, over 70\% of US military facilities (for exclusive use) in Japan are deployed. US military facilities in Okinawa occupy 188 square kilometres out of the total prefectural area of 2,281 square kilometres, which means that $8.3 \%$ of the prefecture is US military facilities. The concentration is even higher for Okinawa main island, on which US military facilities compose about $15 \%$ of land (Okinawa Prefecture, 2018b: 2). The number of US troops mirrors this land distribution: over 70\%, nearly 26,000 troops, are concentrated in Okinawa prefecture 
(Okinawa Prefecture, undated). In addition, there are roughly 2,000 civilian workers for the military and 19,000 family members (Okinawa Prefecture, 2016).

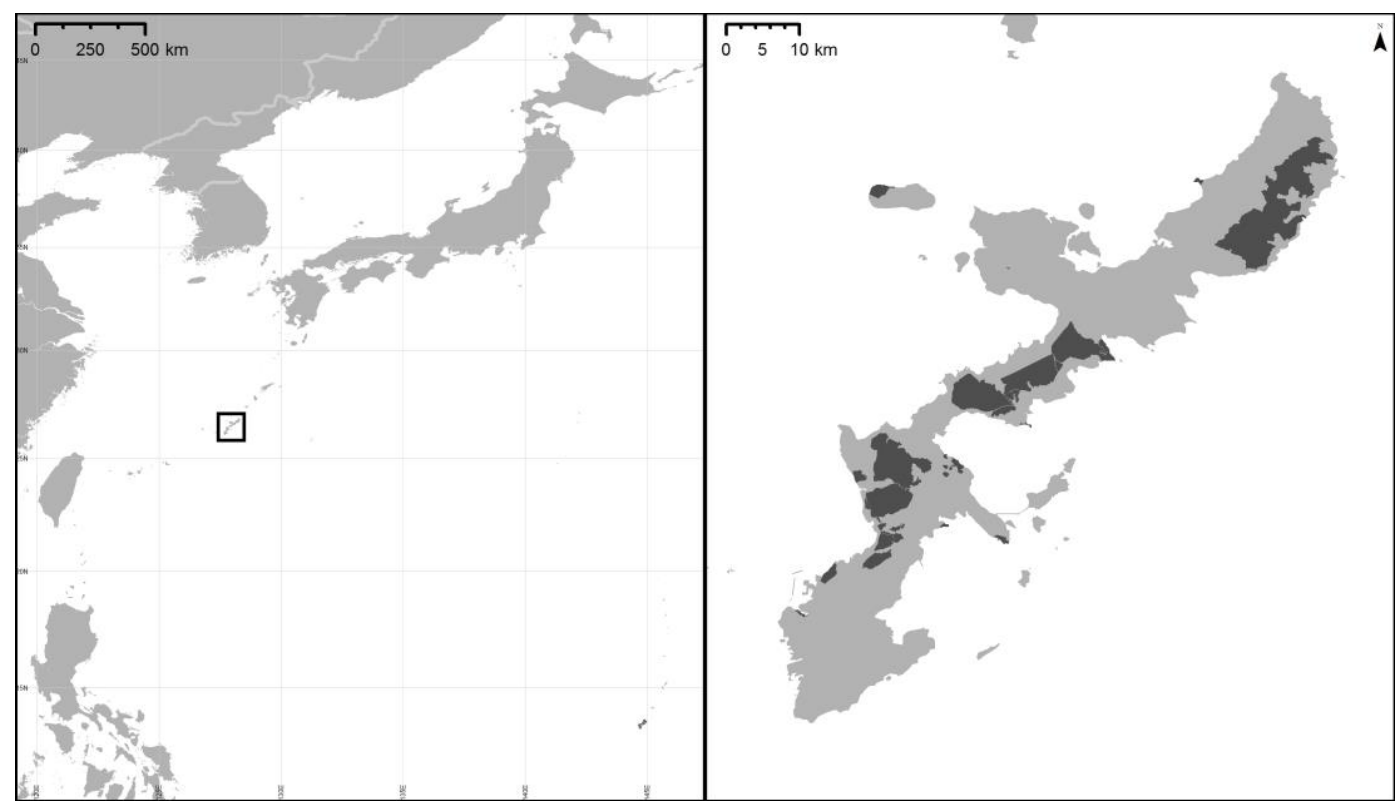

Fig.1 US military bases (areas in black) in Okinawa main island.

The heavy presence of the US military in Okinawa is prone to endanger the lives of local residents, causing insecurity of the islanders in the name of national and international security (Akibayashi \& Takazato, 2009; Hoshino, 2013). The US military in Okinawa is established under the postwar USJapan security alliance. It is often said among state officials that the bilateral alliance is crucial for Japan's national, regional and international security. The demilitarisation of the country and regional security issues, ranging from the Korean and Vietnam Wars to more recent perceived threats such as the rise of China and the North Korean nuclear programme, have been given as justifications for the security alliance. For Japan and the US alike, Okinawa is seen as a particularly important military location with respect to maintaining regional security. However, the same military that is said to promote security has also caused insecurity among Okinawans. According to the Okinawa Prefectural Governor's Office (Okinawa Prefecture, undated), 709 accidents related to US military planes have been recorded from 1972 to 2016. In the same period, there have been 
nearly 6,000 crimes committed by US military members, of which roughly 600 cases are felonious offences (kyōakuhan) including robbery, murder and rape. Despite the persistence of these issues, the Japanese government has not pursued any significant changes to the uneven distribution of US military.

Consequently, many Okinawans have joined resistance movements against US bases over the past decades. They continue to resist the hegemonic narratives of security produced by Japan and the United States. Local residents participate in sit-in protests around bases. Cases of rape have particularly enraged the people of Okinawa. Tens of thousands of Okinawans participated in an anti-base protest in the aftermath of the 1995 gang rape of a 12-year-old girl by three US service men. The recent rape and murder of a 20-year-old woman by a US base worker in 2016 has led to large-scale demonstration. Anti-base organisations were also founded, including Okinawa Women Act Against Military Violence that was established in 1995. Beyond issues around US bases, Okinawans continue to challenge Japan's ongoing imperial discourses that have repeatedly downplayed the colonial past of Okinawa. Activists have appealed to the United Nations Human Rights Council for recognition of their indigenous status of Okinawans, which the government continues to refuse to recognise (UN Human Rights Council, 2012). Moreover, there have been local initiatives to rewrite dominant historical accounts produced by the central government. In 2007, for example, 110,000 Okinawans protested against the Ministry of Education, Culture, Sports, Science and Technology's objection to the inclusion of incidents of mass suicide during the Battle of Okinawa in high school textbooks (Aniya, 2008).

As such, Okinawa is described and discussed among scholars and activists in terms of anti-base and demilitarisation movements. As McCormack and Norimatsu (2012) put it, Okinawa represents "resistant islands". Their very act of refusing bases exhibits critical interventions to the dominant 
understanding of geopolitics. They problematise the ubiquity and everydayness of contemporary war and conflict in islands and offer islanders' perspectives that are typically ignored in the national and international discourse of security. However, while resistance is undoubtedly crucial for understanding contemporary imperial geopolitics, it does not recognise complex mechanisms that exist in colonial life on Okinawa and that affect the minds of Okinawans.

\section{MAKING A LIVING AND HAVING TO DISREGARD}

Okinawans are certainly not Valck, the protagonist in Stoler's analysis of the politics of disregard. They do not live off empire as Valck did. Their acts of disregard are not the same as acts of disregard among the colonisers. Given Okinawa's colonial past and present, it would be misleading, if not completely inappropriate, to treat local residents who work in bases and base-related industries in Okinawa as those "with privilege and standing" (Stoler, 2009: 256). Yet, they too make, and have to make, a living within the colonial enterprise. In doing so, they too disregard certain colonial conditions in their everyday lives, albeit without fully accepting or submitting themselves to existing imperial structures.

The postcolonial conception that colonialism can be neither simply accepted nor refused helps to recognise the existence of multiple, often contradicting, feelings and sentiments that Okinawans go through in the militarised island. Certainly, like other decolonisation and demilitarisation struggles across the world (Davis, 2015), explicit resistance against bases does not only exist but is prevalent in Okinawa. As discussed in the previous section, many Okinawans continue to resist the hegemonic narratives of security and dominant historical accounts on Okinawa's colonial past and present. At the same time, existing studies have argued that there are also those who "accept" the colonial and militarized conditions of Okinawa. For some Okinawans US bases are seen as economic opportunities: "for some, the bases are 'good"” (Hook and Siddle, 2002: 4). Okinawa 
continues to suffer from the highest unemployment rates and the lowest average income in Japan. The lack of stable jobs in private local sectors drives the popularity of jobs in bases, particularly among young Okinawans. In 2003, for example, the unemployment rate was nearly $8 \%$, compared to the national average of 5\%. The difference was even higher among young Okinawans: for them the unemployment rate was over $18 \%$, which is nearly two times higher than the national average of young people of $10 \%$. In the same year, it was reported that there were 15,582 applications for only 675 jobs in bases (more than 23 applications per job) (Asahi Shimbun, 2004). The popularity is also due to the perceived quality of base jobs: compared to private sectors, they are typically better paid and seen more reliable as the government makes these payments. In addition, a significant number of landowners continue to receive payments from the government for leasing land to the military. In the same year, there were more than 32,000 landowners who in total received over 76.4 billion yen in compensation (Calder, 2007: 171). The so-called "military land" (gunyōchi) remains a popular investment and is traded across local estate agents in Okinawa to this day. Outside of bases, local service sectors are considered to benefit from the presence of US bases as consumption expenditure is typically expected to grow in the surrounding areas.

Economic prospects of US bases have contributed to an "identity crisis" (Idaka, 2001) in Okinawa where people are oscillating between resistance against and support for bases. They have created "pro-American segments" in Okinawa, which has a geographical character (Yamazaki, 2010: 267). Following Agnew (1996), Yamazaki (2005) suggests that there are geographical patterns in voting behaviour in Okinawa. For example, following the 1995 gang rape incident and mass anti-base demonstrations, the anti-base governor Ōta Masahide set the prefectural referendum on review of the Japan-US Status of Forces Agreement of bases in 1996. The referendum's result showed that local residents from municipalities with a high concentration of bases were more likely to oppose the reduction of bases whilst those from municipalities with a high level of income were more likely 
to support the reduction (Yamazaki, 2005: 60). This somewhat "paradoxical" (Yamazaki, 2005: 76) behaviour was due to the fact that people in these municipalities tended to rely on income derived from base-related industries.

The geography of pro- and anti-base Okinawans may have been translated into the recent Nago mayoral election in 2018. The Nago election is a high-profile local election, typically with a high voter turnout of over $75 \%$ over the past decade or so, as its result can have a major impact on the politics of US bases. The city not only has Camp Schwab on its east coast Cape Henoko since the period of US military occupation, but also is a new base construction site today. Henoko is a major destination for the planned "return" (relocation, in practice) of the Marine Corps Air Station Futenma, which is sometimes said to be the world's most dangerous base (Vine, 2015: 264) because of its location surrounded by a densely populated residential area of Ginowan. The FutenmaHenoko relocation plan was proposed as early as in the late 1990s and has been supported by the conservative governments of Japan and the United States. In the highly anticipated mayoral election in February 2018, the conservative-government-backed candidate Toguchi Taketoyo won the election against the incumbent and anti-relocation mayor Inamine Susumu despite anti-base and anti-relocation movements across Okinawa for more than a decade.

Supporters of Toguchi typically expressed in a number of interviews conducted by local and national newspapers that their priority is the local economy and that a new base would bring economic benefits (Asahi Shimbun, 2018; Mainichi Shimbun, 2018; Okinawa Times, 2018b). Some highlighted a geographical gap in understanding life with a base and convey a sense of irritation towards anti-relocation demonstrations outside of the city. A 34-year-old resident of Nago who works in a shop inside a base spoke to Mainichi Shimbun (2018) before the election: "The locals have been working well with the base. I don't want to be told by surrounding people what to do". 
The economy of Nago, one of the biggest municipalities in Okinawa with the population of over 60,000 , is stagnant. The city has an average income lower than the prefectural average for the past decade (Okinawa Prefecture, 2018a). According to the $e$-Stat database (a portal site for government statistics), the municipal unemployment rate had also been higher than the prefectural average until 2015 when it declined to $5.1 \%$ compared to the prefectural average of $6.3 \%$, which is still higher than the national average of $4.2 \%$. In addition, the recent increase in the number of tourists to Okinawa and corresponding growing tourism industry have an uneven geographical economic impact. Compared to major tourist destinations in the main island such as the Churaumi Aquarium in Motobu, cities like Nago are often "passed through" (sudōri kanko) by tourists. Also expressed were a general defeatism and tiredness in part due to Okinawa's eventual loss in lawsuit against the central government over rescinding the previously agreed Henoko construction plan in 2016 and the fact that the construction is already underway. Combined with these aspects, economic prospects of bases were translated to residents' opinions about the relocation plan during the 2018 election, which ended eight years of the anti-relocation municipal office.

However, the eventual victory of Toguchi, and effectively, that of the conservative government's construction plan, suggests a more complex situation of living in areas surrounding bases. Despite economic prospects, general opposition to bases has hardly ceased in Nago. In fact, several polls conducted by local and national news media show the overall opposition to the Futenma-Henoko relocation. One exist poll shows that nearly $65 \%$ of respondents are opposed to the relocation (Okinawa Times, 2018a). Another exit poll conducted by NHK (2018) shows even stronger opposition: $75 \%$ of respondents disagree with the relocation. The limitations of polls should be noted: for example, in one of exit polls, nearly half of those who were asked to participate refused to answer (Okinawa Times, 2018a); and, two major newspapers, Okinawa Times and Ryukyu Shimpo, are by and large opposed to the presence of US bases, which may have shaped the image of 
socially acceptable residents of Okinawa. Yet, beyond response biases, the loss of the antirelocation mayor despite continuous general support for the opposition to the government's plan also reflects on complex and ambivalent feelings that span the minds of local residents. One may reasonably "disagree" with the relocation plan yet may support the base-permissive mayor for better economic prospects.

Speaking to Asahi Shimbun (2018) after the election, a 44-year-old resident of Nago said that he voted for Toguchi although he, in principle, prefers not to have a base in the city. "There is nothing better than not having a base", he says, having previously supported the anti-relocation mayor over the last two elections. But his decisive concern this time was the stagnant economy of the city that has affected him and his friend who went bankrupt. Another senior resident of Nago also voted for Toguchi even though he opposes the Henoko relocation. While he too was against the relocation, he "wanted to change the stagnant atmosphere [of Nago]" (Asahi Shimbun, 2018). Similarly, a $62-$ year-old resident who works in a restaurant whose customers include US soldiers told the newspaper her decision to support Toguchi: “My life depends on it. It can't be helped that a base is coming. Bring some money from the country" (Asahi Shimbun, 2018).

What these anecdotes attest to is the contradictions and ambiguity that they face in their everyday lives, or what I would suggest the operation of the geopolitics of disregard. Supporting the centralgovernment-backed mayor, and in practice complying with the construction plan and with ongoing de facto military colonialism, does not mean that they are in favour of US bases. Nor are these supporters ignorant about the potential consequences of their decision or about the (post-)colonial conditions they live in. Ambivalence inherent in the presence of US bases in Okinawa does not just divide local residents into pro-base Okinawans and anti-base Okinawans. Instead, it also spans within individual minds. These local residents come to comply with the construction of a new base 
because of a stagnant local economy while in principle opposing the presence of US bases. Equally, resistance and direct action against the Futenma-Henoko relocation, and against US bases in general, represent only one aspect of Okinawa's (post)colonial complex (cf. Hoshino, 2018).

Okinawans also go through what Stoler characterises as the "complex psychic space" in which they "decide" to live with, and make a living from, US bases. I use inverted commas for the term "decide" here to signal that their decisions are deeply embedded within the structure of Okinawa's military economy and stagnation in local industries, which have affected cities like Nago. In making a living from military-related industries (or hoping to do so), they come to disregard particular colonial conditions they inhabit. Imperial dispositions are translated into the minds of the colonised who avert their gaze from military (post)colonialism. In doing so, they contribute to the reproduction of two imperial geopolitical orders. On the one hand, Japanese (post-)imperialism continues as a form of uneven distribution of foreign bases, which is excused by a series of the government's aids and subsidies. On the other hand, by providing land, infrastructures, and services, all of which remain important sources of income for local residents, they contribute to sustaining US imperial geopolitics, which was established during an earlier period of military colonialism.

\section{AGENDAS FOR GEOPOLITICS OF DISREGARD IN AND BEYOND OKINAWA}

The reproduction of imperial geopolitical orders through acts of disregard among the colonised poses a challenge to a contemporary demilitarisation and decolonisation process in Okinawa and other militarised islands. The intense militarisation of islands such as Hawaii, Okinawa, Guam, and Puerto Rico have caused various kinds of violence to islanders and as a result, there are constant resistance movements across these islands. Davis (2015: 73-4, italic original) characterises these islands as "repeating islands of resistance" not just because resistance movements are repeating 
within each island but also because "the spirit of resistance repeats from island to island". Within militarised islands, Davis (2015: 70-90) argues, resistance movements are often formed by people living near bases because of immediate impacts that military training can cause. In Okinawa, military training has indeed caused resistance movements. For example, the 2004 helicopter crash onto Okinawa International University in Ginowan led to anti-base demonstrations, particularly against the Futenma base. The ruins of the crash have been preserved as monuments and the university holds an annual commemoration on $13^{\text {th }}$ August. However, as this article discussed, it is also these areas near bases where local residents come to disregard the very structure of imperial geopolitics and violence the militarisation of these places can cause.

The issue here is not exclusive to the particular geographical context of Okinawa. Just as much as colonial militarisation and corresponding resistance movements operate across different islands in the Pacific and beyond (Davis, 2015; Lutz, 2009; Vine, 2015), a study of disregard is of relevance in other militarised islands. Guam, for example, is an equally highly militarised island and has a military-(colonial)-industrial complex. Like Okinawa, intense militarisation co-exists with high poverty and unemployment rates in Guam. Consequently, many of its residents are, one way or another, associated with bases and related industries (Vine, 2015: 89). As suggested in this article, the combination of poor local economy and the economic prospects of bases contributes to ambivalence that spans both across and within islanders. But the case of Guam, or more precisely an interisland perspective from Guam and Okinawa, suggests not only the importance of understanding such ambivalence within different islands but also a need to understand it at and across different scales.

An interisland perspective can offer more complex spatial insights into the contemporary geopolitics of islands. Like existing political geographies of islands and archipelagos, its focus is 
centred upon islands as "remote" and peripheral zones of sovereignty, which challenges the conventional understandings of "bounded" territory, national security, migration management, and military operation (Mountz, 2011, 2015). The issue here, however, does not simply concern the relations between islands and the mainland, but between one island and another, between those already offshored sites of sovereign power (Mountz, 2013). From an interisland perspective, the relationship between imperial geopolitics, resistance movements, and acts of disregard become more intricate. Anti-base resistance movements may successfully mobilise an empire to demilitarise, either partially or wholly, an island. Yet, this very mobilisation of anti-base movements can risk promoting further militarisation of other islands at the same time. Albeit very limited in implementation to this day, anti-base movements in Okinawa in the past have led to changes in policies concerning US bases. In 2006, the Japanese government and the United States agreed with a plan to relocate US Marines from the Futenma base, partly to Cape Henoko and partly to Guam (Ministry of Foreign Affairs of Japan, 2006). The revised agreement in 2012 reaffirmed the Okinawa-Guam relocation with additional destination locations (U.S. Department of Defense, 2012). More recently, in 2017, Commander of the US Pacific Command, Admiral Harry Harris, testified to Congress about the Okinawa-Guam relocation plan. According to this plan, somewhere between 4,000 and 19,000 Marines currently stationed in Okinawa will be transferred to Guam during the period between 2024 and 2028 (Chanlett-Avery \& Mann, 2017). Corresponding buildup and expansion plans in Guam have met, though smaller in scale compared to those in Okinawa, opposition and resistance in the past. Indigenous Chamorro people continue to oppose expansion plans, who are often working together with anti-base organisations abroad including activists in Okinawa (Natividad \& Kirk, 2010). That is to say, despite anti-militarist networks in the pacific (Davis, 2015), a military build-up and resistance against it in one place are closely entwined with (relatively) successful anti-base movements in elsewhere. 
Militarisation and anti-militarisation travel across islands, and so does the ambivalence provoked by bases. As in the case of Okinawa, the presence of resistance in Guam does not necessarily override economic prospects that a military build-up may offer (Natividad \& Kirk, 2010; Vine, 2015: 89-93). In light of a proposed build-up in 2016, which was part of the Futenma relocation plan, The Guardian (2016) reported that there are both opposition to and support for the build-up. It is reported that local residents in Guam, particularly in the island's business community, show support for the build-up due to the island's "fragile" economy and benefits the build-up can bring. Speaking to the newspaper (The Guardian, 2016), Vivian Dames, retired associate professor at the University of Guam and host of a Guam Public Radio (KPRG) programme, notes a complexity in the politics of bases in Guam in which one cannot simply be "for or against" the build-up. A further complexity is that resistance against a build-up is not always resistance against military bases themselves. It “doesn't translate into hating the military", said Leevin Camacho, a spokesperson of We Are Guåhan, whose father has been an enlisted soldier for more than two decades (cited in Vine, 2015: 92). Despite resistance movements, Natividad and Kirk (2010: 14) suggest, the island's decades-old relationship with, and dependency on, bases has shaped islanders' attitudes towards ongoing colonisation and militarisation: “islanders' U.S. patriotism runs deep with wartime experiences as recent as World War II and the 'liberation' of the island from Japan by U.S. forces. Guam is heavily dependent on the military, which shapes the local economy, patterns of land-use, political priorities, and perhaps most dangerously, the psyches of the people".

The history, economy, and politics of militarisation varies from one island to another and geographical differences must be taken into account. They are different in, for example, demography (unlike Okinawa, more than half of residents in Guam are from outside of the island), territorial status (a Japanese prefecture compared to a US unincorporated territory), and political rights (the presence/absence of a voting right). Each island's relationship to an empire certainly 
varies. Nonetheless, the ambivalent nature of bases seems to prevail across militarised islands and, correspondingly, local residents avert their gaze from particular colonial conditions they live in. A particular challenge arises in the fact that those who appear to comply with the militarisation of their everyday lives do not necessarily support the presence of bases themselves, as expressed by residents of Nago. As Stoler suggests, rather than it being something one can accept or refuse, (contemporary) colonialism intrudes deep into the minds of these living under conditions of empire.

This is not an endorsement of pessimism about the future of the colonial and militarised islands. Rather, it is a call to explore and recognise the multiple entanglements of contemporary imperial geopolitics and everyday life in these islands beyond the conventional representation of geographies of militarised islands. In his ethnographic study of Palestine, Harker (2009) cautions that the predetermined representation of Palestinian geographies almost exclusively in terms of the Israeli Occupation runs the risk of not apprehending complexities in the lives of Palestinians. Their lives are closely linked to the occupation but never wholly determined by it. What is occupied is more than abstract concepts of territory and population and there is a greater need for research on the singular embodied experience of people under occupation (Handel, 2016). The experiences of Okinawans (and other islanders), which the present study explored and are to be explored further through, for example, ethnographic methods, diaries, and other sources as Handel (2016: 86) suggests, helps to understand the geopolitics of Okinawa in a way that is informed by yet irreducible to the framework of (de-)militarisation. If critical geopolitics is to understand the mutually constitutive nature of geopolitics and everyday life and to bring out the voice of the marginalised, its scope of analysis should also extend to what it means and takes to live, and to make a living, in colonial and militarised islands. 


\section{$\underline{\text { BIBLIOGRAPHY }}$}

Agnew, J. (1996). Mapping politics: how context counts in electoral geography. Political Geography, 15(2). 129-146.

Akibayashi, K., \& Takazato, S. (2009). Okinawa: Women's Struggle for Demilitarization. In C. Lutz (Ed.), The Bases of Empire: The Global Struggle against U.S. Military Posts (pp. 243269). London: Pluto Press.

Aniya, M. (2008) Compulsory Mass Suicide, the Battle of Okinawa, and Japan's Textbook Controversy. Japan Focus: The Asia-Pacific Journal, 6(1), 1-13.

Asahi Shimbun (2004). Okinawa, kichikyūjin ni sattō. Shitsugyōritsu zenkoku ichi. 13 May. http://www.asahi.com/area/okinawa/articles/MTW20999999480150570.html. Accessed 13.11.18.

Asahi Shimbun (2018). Henoko isetsu "hantai dakedo ..." nago shichōsen, yūkensha no omoi. 5 February. https://www.asahi.com/articles/ASL247X6BL24TIPE01T.html. Accessed 14.11.18.

Bhabha, H. K. (2004). The Location of Culture. Oxon: Routledge.

Billig, M. (1995). Banal Nationalism. London: Sage.

Blunt, A. \& McEwan, C. (2002). Introduction. In A. Blunt \& C. McEwan (Eds.), Postcolonial Geographies (pp. 1-6). London: Continuum.

Calder, K.E. (2007). Embattled Garrisons: Comparative Base Politics and American Globalism. Princeton: Princeton University Press.

Chanlett-Avery, E. \& Mann, C. T. (2017). U.S. Military Presence on Okinawa and Realignment to Guam. Congressional Research Service in Focus. 14 June. https://fas.org/sgp/crs/row/IF10672.pdf. Accessed 14.11.18.

Ciută, F. \& Klinke, I. (2010). Lost in conceptualization: Reading the "the new Cold War" with critical geopolitics. Political Geography, 29(6), 323-332. 
Dalby, S. (2008). Imperialism, Domination, Culture: The Continued Relevance of Critical Geopolitics. Geopolitics, 13(3), 413-436.

Dalby, S. (2010). Recontextualising violence, power and nature: The next twenty years of critical geopolitics? Political Geography, 29, 280-288.

Davis, S. (2011). The US military base network and contemporary colonialism: Power projection, resistance and the quest for operational unilateralism. Political Geography, 30, 215-224.

Davis, S. (2015). The Empire's Edge: Militarization, Resistance, and Transcending Hegemony in the Pacific. Athens: The University of Georgia Press.

Dittmer, J., \& Dodds, K. (2008). Popular Geopolitics Past and Future: Fandom, Identities and Audiences. Geopolitics, 13(3), 437-457.

Dodds, K. (2000). Political geography II: some thoughts on banality, new wars and the geopolitical tradition. Progress in Human Geography, 24(1), 119-129.

Dodds, K. (2001). Political geography III: critical geopolitics after ten years. Progress in Human Geography, 25(3), 469-484.

Dodds, K., Kuus, M., \& Sharp, J. (Eds.) (2013). The Ashgate Research Companion to Critical Geopolitics. Surrey: Ashgate.

Dowler, L., \& Sharp, J. (2001). A Feminist Geopolitics? Space and Polity, 5(3), 165-176.

Du Bois, W. E. B. (1920). Darkwater: Voices from Within the Veil. New York: Harcourt, Brace and Howe.

Gregory, D. (2004). The Colonial Present. Oxford: Blackwell Publishing.

Handel, A. (2016). Guest Editorial. What is occupied in Palestine? Political Geography, 53, 86-88.

Harker, C. (2009). Spacing Palestine through the home. Transactions of the Institute of British Geographers, 34(3), 320-332.

Harvey, D. (2005). The New Imperialism. Oxford: Oxford University Press. 
Herman, R.D.K. (2008). Inscribing empire: Guam and the War in the Pacific National Historical Park. Political Geography, 27(6), 630-651.

Hook, G.D., \& Siddle, R. (2002). Introduction: Japan? Structure and subjectivity in Okinawa. In G.D. Hook \& R. Siddle (Eds.), Japan and Okinawa: Structure and subjectivity (pp. 1-17). London: Routledge.

Hoshino, E. (2013). Okinawa no beigun kichi mondai to ningen no anzen hoshō. Review of policy science and international relations, 15, 23-59.

Hoshino, E. (2018). The Postcolonial Complex in Okinawa. In O.U. Rutazibwa \& R. Shilliam (Eds.) Routledge Handbook of Postcolonial Politics (pp. 239-254). Oxon: Routledge.

Hyndman, J. (2007). Feminist Geopolitics Revisited: Body Counts in Iraq. The Professional Geographers, 59(1), 35-46.

Idaka, H. (2001). Sōtō no Okinawa. Tokyo: Gendaikikakushitsu.

Immerwahr, D. (2019). How to Hide an Empire: A History of the Greater United States. New York: Farrar, Straus and Giroux.

Kuus, M. (2007). "Love, Peace and Nato": Imperial Subject-Making in Central Europe. Antipode, 39(2), 269-290.

Lutz, C. (Ed.) (2009). The Bases of Empire: The Global Struggle against U.S. Military Posts. London: Pluto Press.

Mainichi Shimbun (2018). Nago shichōsen. Susumanu shinkō, tomaranu isetsu, henoko omoi fukuzatsu. 2 February. https://mainichi.jp/articles/20180202/k00/00e/010/220000c. Accessed 19.11.18.

McConnell, F. (2017). Liminal geopolitics: the subjectivity and spatiality of diplomacy at the margins. Transactions of the Institute of British Geographers, 42(1), 139-152.

McCormack, G. \& Norimatsu, S.O. (2012). Resistant Islands: Okinawa Confronts Japan and the United States. Lanham: Rowman \& Littlefield Publishers. 
Memmi, A. (2003). The Colonizer and the Colonized. London: Earthscan Publications.

Mercille, J. (2008). The radical geopolitics of US foreign policy: Geopolitical and geoeconomic logics of power. Political Geography, 27(5), 570-586.

Ministry of Foreign Affairs of Japan (2006). United States-Japan Roadmap for Realignment Implementation. https://www.mofa.go.jp/region/n-america/us/security/scc/doc0605.html. Accessed 14.11.18.

Mountz, A. (2011). The enforcement archipelago: Detention, haunting, and asylum on islands. Political Geography, 30(3), 118-128.

Mountz, A. (2013). Political Geography I: Reconfiguring geographies of sovereignty. Progress in Human Geography, 37(6), 829-841.

Mountz, A. (2015). Political Geography II: Islands and archipelagos. Progress in Human Geography, 39(5), 636-646.

Natividad, L. \& Kirk, G. (2010). Fortress Guam: Resistance to US Military Mega-Buildup. Japan Focus, 8(19): 1-17.

NHK (2018). Micchaku. Nago shichōsen. Kichi isetsu kōji ga susumu machide. 5 February. https://www.nhk.or.jp/gendai/articles/4096/index.html. Accessed 16.11.18.

Oguma, E. (2014). The Boundaries of "the Japanese” Volume 1: Okinawa 1868-1972, Inclusion and Exclusion. Melbourne: Trans Pacific Press.

Okinawa Prefecture (2016). Beigun teikyō shisetsu, kuiki no gaiyō. 12 January. .

Okinawa Prefecture (2018a). Heisei 27 nendo Okinawaken shichōsonmin shutoku. 10 October. https://www.pref.okinawa.jp/toukeika/ctv/ctv_index.html. Accessed 21.11.18.

Okinawa Prefecture (2018b). Okinawa no sugata (kensei gaiyō). June. https://www.pref.okinawa.jp/site/kikaku/chosei/keikaku/h24-okinawanosugata.html. Accessed 19.11.18. 
Okinawa Prefecture (undated). Sūji de miru Okinawa no beigun kichi. http://www.pref.okinawa.jp/site/chijiko/kichitai/tyosa/documents/p32.pdf. Accessed 25.06.18.

Okinawa Times (2018a). Henoko isetsu no sanpi, jyūshi shita seisaku wa? Nago shichōsen 2018, deguchi chōsa. 5 February. https://www.okinawatimes.co.jp/articles/-/204909. Accessed 16.11.18.

Okinawa Times (2018b). Nago shichōsen: 2018: kichi, kōfukin, fukkō, kurashi ... tōjiru 1 ppyō nayamu yūkensha. 1 February. https://www.okinawatimes.co.jp/articles/-/203496. Accessed 19.11.18.

Ó Tuathail, G. (1996). Critical Geopolitics: The Politics of Writing Global Space. London: Routledge.

Paasi, A. (1996). Territories, boundaries and consciousness: the changing geographies of the Finnish-Russian border. Chichester: John Wiley \& Sons.

Paasi, A. (2016). Dancing on the graves: Independence, hot/banal nationalism and the mobilization of memory. Political Geography, 54, 21-31.

Power, M. and Campbell, D. (2010). Guest Editorial. The State of critical geopolitics. Political Geography, 29(5), 243-246.

Said, E. W. (2001). The Clash of Ignorance. The Nations. 3 October. https://www.thenation.com/article/clash-ignorance/. Accessed 15.06.18.

Sharp, J. (2000). Remasculinising geo-politics? Comments on Gearoid O'Tuathail's Critical Geopolitics. Political Geography, 19(3), 361-364.

Sharp, J. (2011a). A subaltern critical geopolitics of the war on terror: Postcolonial security in Tanzania. Geoforum, 42(3), 297-305.

Sharp, J. (2011b). Editorial. Subaltern geopolitics: Introduction. Geoforum, 42(3), 271-273.

Sharp, J. (2013). Geopolitics at the margins? Reconsidering genealogies of critical geopolitics. Political Geography, 37, 20-29. 
Sidaway, J. D. (2000). Postcolonial geographies: an exploratory essay. Progress in Human Geography, 24(4), 591-612.

Sidaway, J. D. (2008). The Dissemination of Banal Geopolitics: Webs of Extremism and Insecurity. Antipode, 40(1), 2-8.

Sidaway, J. D. (2010). “One Island, One Team, One Mission”: Geopolitics, Sovereignty, "Race” and Rendition. Geopolitics, 15(4), 667-683.

Sidaway, J. D. (2012). Commentary. Subaltern geopolitics: Libya in the mirror of Europe. The Geographical Journal, 178(4), 296-301.

Sidaway, J. D., Mamadouh, V., \& Power, M. (2013). Reappraising Geopolitical Traditions. In K. Dodds, M. Kuus, \& J. Sharp (Eds.), The Ashgate Research Companion to Critical Geopolitics (pp. 165-188). Surrey: Ashgate.

Siddle, R. (1998). Colonialism and identity in Okinawa before 1945. Japanese Studies, 18(2), 117133.

Simmel, G. (1950). The Sociology of Georg Simmel. Illinois: The Free Press.

Slater, D. (2004). Geopolitics and the Post-colonial: Rethinking North-South Relations. Oxford: Blackwell Publishing.

Stoler, A.L. (2009). Along the Archival Grain: Epistemic Anxieties and Colonial Common Sense. Princeton: Princeton University Press.

The White House President Barack Obama (2016). Remarks by President Obama and Prime Minister Abe after Bilateral Meeting. 25 May. https://obamawhitehouse.archives.gov/the-pressoffice/2016/05/25/remarks-president-obama-and-prime-minister-abe-after-bilateral-meeting. Accessed 29.06.18.

UN Human Rights Council (2012). Written statement submitted by the International Movement against All Forms of Discrimination and Racism (IMADR), a non-governmental organization in 
special consultative status. Japan: Violation of human rights of indigenous peoples of Ryukyus in Okinawa. A/HRC/20/NGO/20 (8 June).

U.S. Department of Defense (2012). News Release: Joint Statement of the Security Consultative Committee. 26 April. http://archive.defense.gov/releases/release.aspx?releaseid=15220. Accessed 20.11.18.

Vine, D. (2009). Island of Shame: The Secret History of the U.S. Military Base on Diego Garcia. Princeton: Princeton University Press.

Vine, D. (2015). Base Nation: How U.S. Military Abroad Harm America and the World. New York: Metropolitan Books.

Thrift, N. (2010). It's the little things. In K. Dodds \& D. Atkinson (Eds.). Geopolitical traditions: Critical histories of a century of geopolitical thought (pp. 380-387). London: Routledge.

Weiner, M. (1997). The Invention of Identity: Race and Nation in Pre-war Japan. In F. Dikötter (Ed.), The Construction of Racial Identities in China and Japan (pp. 96-117). Hong Kong: Hong Kong University Press.

Woon, C. Y. (2011). Undoing violence, unbounding precarity: Beyond the frames of terror in the Philippines. Geoforum, 42(3), 285-296.

Yamazaki, T. (2005). Sengo Okinawa ni okeru shakai undo to tōhyō kōdō no kankeisei ni kansuru seiji chirigakuteki kenkyū. Osaka: For You.

Yamazaki, T. (2011) The US Militarization of a 'Host' Civilian Society: The Case of Postwar Okinawa, Japan. In S. Kirsch, \& C. Flint (Eds.), Reconstructing Conflict: Integrating War and Post-War Geographies (pp. 253-272). Surrey: Ashgate. 